\title{
NILAI PENDIDIKAN KARAKTER CERITA RAKYAT SUKU PASEMAH BENGKULU DAN RELEVANSINYA SEBAGAI MATERI PEMBELAJARAN SASTRA
}

\author{
Fitra Youpika dan Darmiyati Zuchdi \\ Program Pascasarjana Universitas Negeri Yogyakarta \\ email: fitrayoupika@gmail.com
}

\begin{abstract}
Abstrak: Penelitian ini bertujuan untuk mendeskripsikan jenis cerita rakyat masyarakat Suku Pasemah Bengkulu, nilai-nilai pendidikan karakter yang terkandung dalam cerita, dan untuk mengetahui relevansinya sebagai materi pembelajaran sastra di sekolah dasar. Data penelitian ini adalah cerita rakyat yang diperoleh dari hasil merekam dan dokumentasi tertulis. Penelitian ini merupakan penelitian analisis konten inferensial. Hasil penelitian menunjukkan bahwa cerita rakyat masyarakat Suku Pasemah Bengkulu terdiri atas dua jenis, yaitu legenda dan dongeng. Nilai pendidikan karakter yang ditemukan dalam legenda, yaitu pemberani, tanggung jawab, peduli sosial, disiplin, rendah hati, dan religius. Nilai pendidikan karakter yang ditemukan dalam dongeng, yaitu cerdik, sabar, patuh, optimis, kerja keras, ikhlas menerima kekalahan, dan menepati janji. Berdasarkan 12 cerita rakyat yang ditemukan, ada 9 cerita yang relevan sebagai materi pembelajaran sastra di sekolah dasar dan ada 3 cerita rakyat yang tidak relevan.
\end{abstract}

Kata Kunci: cerita rakyat, nilai pendidikan karakter, relevansi, materi ajar

\section{THE CHARACTER EDUCATION VALUES IN THE FOLKLORE OF PASEMAH TRIBE BENGKULU AND ITS RELEVANCE AS LITERARY LEARNING MATERIALS}

\begin{abstract}
This study aims at describing the kinds of folklores, the character education values contained in the folklore of society of Pasemah Tribe Bengkulu, as well as determining their relevance as literary learning materials for the primary school. The data of this research were the folklores collected from recordings and written documents. This research used inferential content analysis technique to analyse the data. The results showed that the folklores of the Pasemah tribe in Bengkulu consisted of two kinds, i.e. urban legends and fairy tales. The character education values found in the urban legends were courage, responsibility, social care, discipline, humbleness, and religiousity. The character education values found in the fairy tales were smartness, patience, obedience, optimism, hard working, sincerity in accepting defeat, and keeping promises. Among the 12 folklores found, there were 9 folklores which were relevant for use as literary learning materials for the primary school and three folklores were not relevant.
\end{abstract}

Keywords: folklores, character education values, relevance, teaching materials

\section{PENDAHULUAN}

Pendidikan bukan suatu istilah yang asing lagi di tengah-tengah masyarakat saat ini. Hal itu karena kegiatan pendidikan tidak dapat dipisahkan dengan kehidupan sehari-hari, bahkan di seluruh lapisan kehidupan manusia. Dengan kata lain, bahwa pendidikan begitu penting, sebagaimana pentingnya kebutuhan lain, seperti sandang (pakaian), pangan (makanan), dan papan (perumahan).
Pendidikan yang baik adalah pendidikan yang dapat mempersiapkan anak didik agar mampu mengakses perannya di masa yang akan datang. Artinya, pendidikan hendaknya dapat membekali siswa dengan berbagai macam keterampilan yang dibutuhkan sesuai dengan keadaan zaman, sehingga ia dapat menjalankan dan memenuhi tujuan hidup secara efektif dan efisien. Dengan kata lain, dapat dikatakan bahwa pendidikan merupakan upaya untuk me- 
majukan budi pekerti, pola pikiran, dan jasmani anak yang selaras dengan alam dan masyarakatnya (Wibowo, 2013:2).

Upaya untuk memajukan budi pekerti dari penjelasan di atas menegaskan bahwa pendidikan karakter merupakan kebutuhan yang sangat penting. Oleh karena itu, penanaman nilai-nilai pendidikan karakter harus dimulai sejak dini baik di rumah, di masyarakat, maupun di sekolah. Pendidikan karakter diharapkan dapat menjadikan siswa terampil, berwawasan luas, dan berakhlak mulia. Siswa diharapkan tidak hanya memiliki kemampuan intelektual saja, lebih dari itu anak didik juga diharapkan memiliki karakter yang baik. Kemampuan intelektual yang baik harus diimbangi dengan pendidikan karakter yang baik pula. Dengan demikian, pendidikan karakter akan menghasilkan siswa yang pintar dan berakhlak mulia.

Melihat keadaan yang ada di tengahtengah masyarakat, dalam dunia pendidikan baru-baru ini masih banyak ditemukan kasus pelajar yang menunjukkan masih kurangnya karakter baik yang dimilikinya. Sebagai contoh, masih banyak terjadi penyalahgunaan media elektronik, seperti: internet, menonton film-film yang belum sesuai dengan usia anak, bermain game yang berlebihan, dan lain sebagainya. Selain itu, jika dilihat dari tiga aspek hasil pengembangan kultur sekolah tahun 2010 terlihat bahwa masih kurangnya karakter baik yang ada pada siswa, terutama dari segi kedisiplinan, kejujuran, persaudaraan, dan ketaatan beribadah (Zuchdi, dkk., 2013:114).

Dilihat dari segi kedisiplinan, masih banyak anak yang tidak mengerjakan tugas rumah atau PR yang ditugaskan oleh gurunya. Dilihat dari kejujuran, masih banyak ditemukan siswa yang meminjam atau mengambil barang milik temanya, curang dalam permainan, dan tidak mengakui ke- salahan yang dilakukan. Berdasarkan rasa persaudaraan, masih banyak ditemukan siswa yang bertengkar baik di dalam kelas ataupun di luar kelas. Kemudian, mengenai ketataatan beribadah, ketaatan beribadah dalam hal ini adalah kesediaan anak untuk saling menghormati, baik dengan teman yang seagama maupun yang berbeda. Hal ini menunjukkan bahwa pendidikan karakter sangat penting untuk diajarkan kepada siswa.

Selain apa yang telah dijelaskan di atas, Lickona (2013:20) mengemukakan ada sepuluh indikasi moral anak kurang baik yang perlu diperbaiki dan mendapatkan perhatian lebih agar berubah menjadi lebih baik. Sepuluh indikasi tersebut, yaitu kekerasan dan tindakan anarkis, pencurian, tindakan curang, pengabaian terhadap aturan yang berlaku, tawuran antarsiswa, penggunaan bahasa yang tidak baik, kematangan seksual yang terlalu dini dan penyimpangannya, dan sikap perusakan diri.

Untukmengatasisi atau mencegah terjadinya pemerosotan nilai-nilai karakter anaksepertiyang dikemukakan di atas, pendidikan karakter memiliki peran yang sangat penting. Sehubungan dengan pentingnya pendidikan karakter tersebut, Muslich (2013:15) mengatakan bahwa "pendidikan karakter harus ditanamkan sejak dini dalam pendidikan formal, mulai dari tingkat TK, SD, SMP, SMA, sampai perguruan tinggi". Salah satu upaya untuk mewujudkan pendidikan karakter tersebut dapat dilakukan dengan mengintegrasikannya dalam mata pelajaran Bahasa Indonesia, yaitu dalam pembelajaran sastra.

Banyak pilihan genre sastra yang dapat dijadikan sebagai sarana atau sumber pendidikan karakter. Namun, yang terpenting dalam hal ini adalah melihat kesesuaian atau relevansi karya sastra tersebut dengan materi, kurikulum, dan jenjang siswa 
yang diajarkan. Tentunya, sastra yang dimaksud dalam hal ini tidak hanya terbatas pada sastra-sastra yang sifatnya modern, namun juga sastra-sastra yang bersifat kedaerahan (lokal) atau sastra daerah. Salah satunya adalah sastra lisan yang berupa cerita rakyat.

Cerita rakyat Suku Pasemah Bengkulu termasuk salah satu jenis karya sastra daerah, sekaligus merupakan kebudayaan nusantara yang masih dianut, tumbuh, dan berkembang di tengah-tengah masyarakatnya. Cerita rakyat Suku Pasemah Bengkulu adalah genre sastra lisan yang disampaikan dan diwariskan secara turun-temurun dari generasi ke generasi yang harus dilestarikan atau dipertahankan keberadaannya di tengah-tengah masyarakat.

Terkait dengan pembinaan dan pengembangan sastra daerah seperti yang telah disebutkan di atas, dalam Peraturan Pemerintah RI No. 57 Tahun 2014 tentang Pengembangan, Pembinaan, dan Pelindungan Bahasa dan Sastra, serta Peningkatan Fungsi Bahasa Indonesia Pasal 24 ayat 2 dinyatakan bahwa pembinaan Sastra Daerah dilakukan melalui: (1) pendidikan sastra; (2) pelatihan sastra; (3) penyediaan fasilitas untuk mendorong berkembangnya komunitas sastra; (4) penyediaan fasilitas untuk menyajikan karya sastra; dan (5) penciptaan suasana yang kondusif untuk bersastra.

Dilihat dari Peraturan Pemerintah RI No. 57 Tahun 2014 di atas, salah satu wujud pembinaan dan pengembangan sastra lisan, khususnya cerita rakyat masyarakat Suku Pasemah adalah dengan menjadikannya sebagai materi ajar dalam pembelajaran sastra di sekolah. Namun, yang harus diperhatikan, yaitu nilai pendidikan karakter apa sajakah yang terkandung dalam cerita dan apakah cerita rakyat tersebut relevan atau tidak sebagai materi pembelajaran sastra?
Khususnya dalam hal ini pembelajaran sastra di sekolah dasar.

Kajiantentang nilai pendidikan karakter yang terkandung dalam cerita dan relevansinya sebagai materi pembelajaran sastra di sekolah dasar perlu dilakukan karena merupakan salah satu langkah untuk membentuk karakter siswa sekaligus sebagai perwujudan kecintaan dan pembinaan terhadap kebudayaaan asli nusantara. Dalam hal ini adalah cerita rakyat asli milik masyarakat Suku Pasemah Bengkulu.

Agung (2011:394) mengatakan ada tiga fokus pendidikan karakter, yaitu berfokus pada nilai-nilai ajaran, nilai klarifikasi, dan pengembangan moral. Sejalan dengan tiga fokus pendidikan karakter tersebut, Sugirin (2011:1) menyatakan bahwa pendidikan karakter merupakan sesuatu yang sangat penting dengan tujuan untuk menerapkan nilai-nilai kebaikan dalam kehidupan seharihari. Pendidikan yang dimaksud dalam hal ini adalah pendidikan nilai, pendidikan budi pekerti, pendidikan moral, dan pendidikan watak yang tujuannya adalah untuk memberi keputusan baik buruk, memelihara apa yang baik, dan mewujudkan kebaikan tersebut dalam kehidupan sehari-hari. Wiyani (2013:27-28) menegaskan bahwa pendidikan karakter adalah proses pemberian tuntunan kepada peserta didik untuk menjadi manusia seutuhnya, yang berkarakter dalam dimensi hati, pikir, raga, rasa, dan karsa.

Pendidikan karakter dalam hal ini dapat dikatakan sebagai suatu sistem penanaman nilai-nilai karakter atau pengembangan etika melalui olah pikir, olah hati, olahraga, olah rasa, dan karsa yang meliputi komponen pengetahuan, kesadaran, dan tindakan untuk melaksanakan nilainilai tersebut dalam kehidupan sehari-hari. Olah pikir, olah hati, olahraga, olah rasa, dan karsa dalam hal ini memiliki keterkaitan dan saling melengkapi satu sama lain, 
yang tujuan akhirnya akan bermuara pada pembentukan karakter dan menjadi wujud nilai-nilai budi pekerti luhur.

Jika dilihat dari berbagai pihak, nilai karakter sangat banyak. Secara umum Nurgiyantoro (2013a:441-442) mengatakan bahwa semua persoalan hidup dan kehidupan manusia, termasuk dalam hal ini mengenai nilai-nilai karakter yang penting dalam kehidupan digolongkan menjadi tiga golongan. Ketiga golongan tersebut adalah (1) nilai yang terkait antara manusia dan diri sendiri; (2) hubungan manusia dengan manusia lain dalam lingkup sosial dan alam; dan (3) hubungan manusia dengan Tuhan.

Beraitan dengan sastra, secara umum dikenal ada dua jenis sastra, yaitu sastra lisan dan sastra tulis. Sastra lisan sering dikenal dengan istilah folklore atau cerita rakyat yang telah mentradisi hidup dan dipertahankan oleh masyarakat pemiliknya (Nurgiyantoro, 2013b:10). Dengan demikian, dapat dikatakan bahwa cerita rakyat salah satu bagian dari folklor.

Barone (2011:60) mengemukakan bahwa cerita rakyat merupakan bagian dari sastra tradisional. Ceritanya pendek dan jalan cerita atau peristiwanya sering kali dengan karakter yang baik atau jahat. Selain itu, tokoh dalam cerita yang berupa binatang biasanya memiliki kesamaan karakter dengan manusia.

Berdasarkan penjelasan di atas, dapat disimpulkan bahwa cerita rakyat merupakan salah satu bentuk sastra lisan dari zaman dahulu yang diwariskan secara turuntemurun dari generasi ke generasi, berkembang di kalangan rakyat, tidak diketahui nama pengarangnya. Kemudian cerita rakyat juga dianggap sebagai kepercayaan yang telah mentradisi dalam masyarakat, dipertahankan oleh masyarakat pemiliknya, dan merupakan salah satu bagian dari folklor.
Cerita rakyat terdiri dari berbagai jenis. Bascom menggolongkan cerita rakyat menjadi tiga golongan besar, yaitu mite, legenda, dan dongeng (Danandjaja, 1994:50). Kaitannya dengan pendidikan karakter, Wibowo (2013:131) mengemukakan empat nilai dalam suatu karya sastra yang baik sebagai materi pembelajaran sastra. Empat nilai tersebut, yaitu nilai estetis, nilai humanis, nilai etis, dan nilai religius.

\section{METODE}

Metode yang digunakan dalam penelitian ini adalah metode analisis konten inferensial. Penelitian dilakukan di daerah Padang Guci Kecamatan Kelam Tengah dan Tanjung Kemuning Kabupaten Kaur Provinsi Bengkulu. Subjek penelitian adalah anggota masyarakat asli Suku Pasemah. Instrumen penelian adalah peneliti sendiri (human instrument). Data penelitian diperoleh dari hasil merekam dan dokumentasi tertulis. Data dari dokumen tertulis sebanyak 1 cerita dan data yang diperoleh dari hasil wawancara dan merekam sebanyak 11 cerita. Langkah-langkah pengadaan data meliputi: (1) penentuan sampel; (2) perekaman/pencatatan; dan (3) penentuan satuan unit. Keabsahan data dilakukan dengan cara mengonsultasikan data kepada pihak ahli (masyarakat). Teknik analisis data yang digunakan, yaitu mengklasifikasikan, memaknai, dan menyimpulkan.

\section{HASIL DAN PEMBAHASAN \\ Jenis Cerita}

Secara umum cerita rakyat ada tiga jenis. Ketiga jenis cerita tersebut, yaitu mite, legenda, dan dongeng.

Adapun cerita yang ditemukan dalam penelitian ini berjumlah 12 cerita. Dari 12 cerita tersebut, 1 cerita merupakan jenis legenda dan 11 cerita jenis dongeng. Cerita jenis legenda tersebut adalah cerita yang 
berjudul "Bujang Remalun”. Kemudian, cerita jenis dongeng, yaitu cerita yang berjudul: (1) Sang Kancil; Siput, dan Lengkukup; (2) Si Miskin; (3) Sang Beruk Besan dengan Kura-kura; (4) Pak Andir; (5) Sang Kancil dan Sang Harimau; (6) Sang Piatu Berdua dengan Nenek; (7) Elang Besan dengan Kura-kura; (8) Janji Kerbau; (9) Pak Beluk; (10) Sang Piatu; dan (11) Sang Setue dan Sang Kancil.

Berdasarkan data di atas, dalam penelitian ini tidak semua jenis cerita rakyat ditemukan. Hasil penelitian menunjukkan tidak ditemukan cerita yang jenisnya berupa mite. Jenis cerita rakyat yang ditemukan hanya legenda dan dongeng.

Dasar bahwa mite tidak ditemukan dalam cerita masyarakat Suku Pasemah Bengkulu Padang Guci karena dari semua data yang ada tidak satu pun cerita yang memenuhi unsur-unsur cerita jenis mite. Unsurunsur suatu cerita yang tergolong mite tersebut berdasarkan pendapat yang dikemukakan oleh Bascom di antaranya adalah tokoh cerita berupa dewa atau makhluk setengah dewa. Selain itu, peristiwa ceritanya bukan terjadi di alam dunia dan peristiwa itu terjadi pada masa lampau (Danandjaja, 1994:50).

Cerita rakyat masyarakat Suku Pasemah Bengkulu yang paling banyak ditemukan adalah jenis cerita dongeng. Dilihat, dari jenis dongeng tersebut yang paling banyak ditemukan adalah dongeng jenis fabel atau dongeng binatang. Fabel atau dongeng binatang tersebutada 6 cerita, yaitu: (1) Sang Kancil, Siput, dan Lengkukup; (2) Sang Beruk Besan dengan Sang Kura; (3) Sang Kancil dan Sang Harimau; (4) Elang Besan dengan Kura-kura; (5) Janji Sang Kerbau; dan (6) Sang Setue dan Sang Kancil.

\section{Karakter Tokoh Cerita}

Ada beberapa tokoh dalam cerita rakyat masyarakat Suku Pasemah Bengkulu berdasarkan masing-masing cerita. Setiap tokoh cerita itu memiliki karakter yang berbeda-beda. Dalam cerita yang berjudul "Bujang Remalaun" tokohnya adalah Bujang Remalun. Dikisahkan Bujang Remalun memiliki karakter yang pemberani, tanggung jawab, rendah hati, disiplin, rela berkorban, iman, takwa, melayani, memiliki visi kepemimpinan, dan setia pada misinya.

Dalam cerita "Sang Kancil, Siput, dan Lengkukup' ada dua tokoh, yaitu kancil, siput, dan lengkukup. Tokoh kancil dalam cerita ini memiliki karakter sombong, angkuh, dan berambisi. Tokoh siput memiliki karakter yang pemberani, bisa bekerja sama dengan teman, dan cerdik. Kemudian, lengkukup memiliki karakter cerdik.

Dalam cerita "Si Miskin" ada dua tokoh, yaitu Ibu dan Anak. Si Ibu dalam cerita memiliki karakter yang kerja keras, sementara Si Anak memiliki karakter sabar. Kemudian, tokoh dalam cerita "Sang Beruk Besan dengan Kura-kura", yaitu beruk dan kura-kura. Beruk dalam cerita ini memiliki karakter yang rakus, tidak sabar, dan tidak tahu terima kasih. Sementara itu, kura-kura memiliki karakter yang suka berbagi dan sabar.

Cerita lainnya adalah cerita yang berjudul "Pak Andir". Dalam cerita ini terdapat dua tokoh, yaitu Pak Andir dan Nduk Andir. Pak Andir dalam kisahnya memiliki karakter yang pemalas dan pamrih, sedangkan Nduk Andir berkarakter cerdik. Kemudian, dalam kisah “Sang Kancil dan Sang Harimau ada dua tokoh juga. Tokoh utama adalah Kancil. Kancil dalam cerita ini memiliki karakter yang cerdik. Kemudian, tokoh lain adalah Harimau. Harimau di sini memiliki sifat ganas, pemaksa, tanpa mem- 
pedulikan teman sekelilingnya, ceroboh, dan tidak mau dilarang.

Ada empat tokoh dalam cerita "Sang Piatu Berdua sama Nenek". Keempat tokoh tersebut, yaitu Sang Piatu, Nenek, Raja, dan Kancil Sepiak. Sang Piatu dalam cerita ini memiliki karakter sabar, optimis, dan toleransi. Tokoh Nenek berkarakter sabar dan pandai bersyukur. Tokoh Raja memiliki karakter iri hati, Kemudian, tokoh Kancil Sepiak memiliki karakter penolong. Kemudian, dalam cerita "Elang Besan dengan $\mathrm{Ku}$ ra-kura" ada dua tokoh. Tokoh tersebut adalah Elang dan Kura-kura. Elang memiliki karakter pengasih dan baik hati, sementara Kura-kura memiliki karakter patuh (penurut) dan mudah terpengaruh.

Karakter tokoh cerita selanjutnya adalah karakter tokoh dalam cerita "Janji Sang Kerbau". Dalam cerita ini ada empat tokoh yang memiliki karakter berbeda-beda. Kerbau memiliki karakter menepati janji, patuh, dan kerja keras. Setue bersifat toleransi. Kancil memiliki karakter penolong dan cerdik. Kemudian, Beruang berkarakter penghasut.

Tiga karakter berikutnya adalah karakter yang ada dalam cerita "Pak Beluk", "Sang Piatu", dan "Sang Setue dan Sang Kancil". Dalam cerita "Pak Beluk" terdapat satu tokoh, yaitu Pak Beluk. Pak Beluk dalam cerita ini memiliki karakter pemalas. Kemudian, dalam cerita "Sang Piatu" juga terdapat satu tokoh yaitu Pak Beluk. Pak Beluk memiliki karakter licik. Terakhir, karakter tokoh dalam cerita "Sang Setue dan Sang Kancil". Dalam cerita ini ada dua cerita, yaitu Sang Setue dan Sang Kancil. Sang Setua memiliki karakter sombong dan Sang Kancil memiliki karakter munafik.

Cerita rakyat masyarakat Suku Pasemah Bengkulu Padang Guci memiliki karakter tokoh yang bermacam-macam. Karakter tokoh tersebut bisa berupa karakter baik dan juga karakter buruk. Kenyataan ini juga ditemukan oleh Nurgiyantoro (2011) dalam penelitiannya yang menyatakan bahwa secara umum cerita wayang terdiri dari dua kelompok karakter tokoh, yaitu karakter baik dan jahat.

Karakter baik atau karakter positif yang ditemukan dalam penelitian ini merupakan karakter tokoh yang patut untuk dijadikan sebagai pembelajaran atau diteladani, sedangkan karakter buruk atau negatif patut ditinggalkan. Namun, bukan berarti karakter negatif tidak perlu diketahui. Karakter negatif penting juga untuk diketahui karena hal itu merupakan sifat yang dapat merugikan diri sendiri dan juga orang lain. Dengan demikian, hal itu harus dihindari.

Hasil penelitian yang ada menunjukkan bahwa dari 12 cerita yang ditemukan terdapat 45 karakter tokoh cerita. Dari 45 karakter tokoh tersebut 10 karakter yang ada dalam cerita BR dan ini sekaligus merupakan karakter yang paling banyak ditemukan dari 12 cerita yang ada. Kemudian, masing-masing sebanyak 6 karakter tokoh dari cerita Sang Kancil; Siput, dan Lengkukup (SKSL) dan Sang Kancil dan Sang Harimau (SKSH), 3 karakter tokoh dalam cerita Si Miskin (SM) dan Pak Andir (PA), 5 karakter dalam cerita Sang Setue dan Sang Kancil (SBBSK), 7 karakter tokoh dalam cerita Sang Piatu Berdua dengan Nenek (SPBDN) dan Janji Sang Kerbau (JSK), 4 karakter tokoh dalam cerita Elang Besan dengan Kura-kura (EBDK), dan masingmasing 1 karakter tokoh dalam cerita Pak Beluk (PB), Sang Piatu (SP), dan Sang Setue dan Sang Kancil (SSSK).

\section{Nilai Pendidikan Karakter dalam Cerita}

Nilai pendidikan karakter dalam penelitian ini diambil dari karakter tokoh dalam cerita yang bersifat baik (positif). Ada- 
pun nilai pendididikan karakter tersebut, yaitu:(1) religius (iman, takwa, dan syukur); (2) tanggung jawab; (3) peduli sosial (mementingkan kepentingan umum, penolong, rela berkorban, kerja sama, suka berbagi, dan pengasih); (4) disiplin; (5) rendah hati; (6) pemberani; (7) cerdik; (8) sabar; (9) patuh; (10); optimis; (11) kerja keras; (12) ikhlas menerima kekalahan; dan (13) menepati janji. Nilai pendidikan karakter tersebut adalah nilai pendidikan karakter yang terkandung dari semua cerita yang ada.

Nilai pendidikan karakter yang ditemukan dalam penelitian ini kemudian digolongkan berdasarkan tiga kategori. Tiga kategori tersebut, yaitu (1) nilai pendidikan karakter terkait dengan diri sendiri; (2) nilai pendidikan karakter terkait dengan orang lain/makhluk lain; dan (3) nilai pendidikan karakter terkait dengan ketuhanan.

Sastra merupakan sarana yang baik sabagai penanaman karakter anak. Hal ini sesuai dengan tujuan dan fungsi karya sastra itu sendiri, yaitu sebagai media penghibur sekaligus sebagai sarana pendidikan. Sastra yang dimaksud baik sastra yang sifatnya baru ataupun sastra yang lama. Termasuk dalam hal ini adalah karya sastra lama yang berupa cerita rakyat. Dengan demikian, secara tidak langsung ini menjadi penting untuk dianalisis tentunya dalam hal ini yang berkaitan dengan nilai-nilai pendidikan karakter dalam suatu karya sastra.

Sastra memiliki banyak nilai pendidikan karakter. Nilai-nilai positif dalam suatu karya sastra tentunya diidentifikasi sebagai sarana untuk mendidik. Secara umum, nilai pendidikan karakter dalam suatu karya sastra dapat dibagi menjadi tiga, yaitu: (1) nilai yang berkaitan dengan diri sendiri; (2) nilai yang berkaitan dengan orang/makhluk lain; dan (3) nilai yang berkaitan dengan ketuhanan. Dari ketiga nilai tersebut, nilai yang paling banyak ditemukan dalam penelitian ini adalah nilai yang terkait dengan orang/ makhluk lain. Hal ini juga terjadi pada penelitian sebelumnya yang dilakukan oleh Rosyiidah (2013), hasilnya menunjukkan bahwa dari pengelompokan nilai karakter yang dilakukan, hubungan karakter yang terkait antara manusia dengan diri sendiri dan manusia dengan sesama paling dominan ditemukan.

Berdasarkan nilai pendidikan karakter di atas nilai yang terkait dengan diri sendiri adalah pemberani, sifat tanggung jawab, disiplin, rendah hati, cerdik, sabar, patuh, optimis, kerja keras, ikhlas menerima kekalahan, dan menepati janji.

Nilai yang terkait dengan diri sendiri yang berupa sifat pemberani dapat ditemukan dalam cerita yang berjudul Bujang Remalun (BR), berjudul Sang Kancil, Siput, dan Lengkukup (SKSL), dan Sang Kancil dan Sang Harimau (SKSH). Sifat tanggung jawab, disiplin, dan rendah hati terdapat dalam cerita Bujang Remalun. Kemudian, nilai yang terkait dengan diri sendiri lainnya adalah sifat cerdik. Cerdik dalam hal ini diartikan sebagai cara atau ide yang dilakukan dalam menghadapi masalah yang ada. Sifat cerdik tersebut terdapat dalam cerita yang berjudul Sang Kancil, Siput, dan Lengkukup (SKSL), Pak Andir (PA), Sang Kancil dan Sang Harimau (SKSH), dan Janji Sang Kerbau (JSK).

Nilai pendidikan karakter yang terkait dengan diri sendiri berikutnya adalah sifat ikhlas menerima kekalahan. Sifat ini terdapat dalam cerita "Sang Kancil, Siput, dan Lengkukup (SKSL)". Kemudian, sifat sabar terdapat dalam cerita Si Miskin (SM), Sang Beruk Besan dengan Kura-kura (SBBSK), dan Sang Piatu Berdua sama Nenek (SPBN). Sifat optimis tercermin dari cerita yang berjudul Sang Piatu Berdua sama Nenek (SPBN). Terakhir, sifat kerja sama terdapat dalam 
cerita Si Miskin (SM) dan Janji Sang Kerbau (JSK).

Selain nilai pendidikan karkter yang terkait dengan diri sendiri, nilai berikutnya adalah nilai pendidikan karakter yang terkait dengan orang/makhluk lain. Adapun nilai pendidikan karakter yang terkait dengan orang/makhluk lain yang ditemukan dalam penelitian ini, yaitu: mementingkan kepentingan umum di atas kepentingan pribadi, penolong, rela berkorban, kerja sama, suka berbagi, dan pengasih.

Nilai yang terkait dengan orang/ makhluk lain yang berupa sifat senang membantu/penolong dapat ditemukan dalam cerita Sang Piatu Berdua sama Nenek, Elang Besan dengan Kura-kura, Janji Kerbau, dan Bujang Remalun. Nilai yang terkait dengan orang/makhluk lain berikutnya adalah sifat toleransi, kerja sama, dan peduli. Sifat toleransi ini dapat ditemukan dalam cerita yang berjudul "Sang Piatu Berdua sama Nenek" dan "Janji Kerbau". Sifat kerja sama terdapat dalam cerita "Sang Kancil, Siput, dan Lengkukup". Sifat peduli ada pada cerita yang berjudul "Sang Beruk Besan dengan Kura-kura". Selanjutnya, sifat "pemurah" dapat ditemukan dalam cerita "Sang Beruk Besan dengan Kura-kura". Sifat "peduli" ada pada cerita "Sang Kancil dan Sang Harimau".

Selanjutnya, nilai yang terkait dengan ketuhanan. Nilai ketuhanan ini yaitu sifat keimanan dan ketakwaan terhadap Tuhan Yang Maha Esa. Nilai yang ditemukan dalam penelitian ini, yaitu iman, takwa, dan syukur. Nilai tersebut terdapat dalam cerita yang berjudul Bujang Remalun. Dalam kisahnya diceritakan Bujang Remalun adalah seorang raja yang bijaksana sakti mandraguna. Ia merupakan seorang pemimpin yang berhasil membuat masyarakatnya aman, damai, dan sejahtera. Setelah rakyatnya aman, damai, dan sejahtera ia memutuskan untuk melakukan pengembaraan panjang yang tidak tahu kapan akhirnya. Pengembaraan panjang itu dilakukannya untuk mencari kebenaran adanya Tuhan Yang Maha Kuasa, yang menguasai alam semesta, yang berkuasa atas langit dan bumi, dan termasuk yang berkuasa terhadap dirinya sendiri, seperti yang ada pada kutipan berikut.

Dalam pengembaraan panjang yang sudah ia putuskan, tujuan yang hendak dicapainya adalah mencari kebenaran atas wasiat yang diterima. Benarkah adanya Tuhan Yang Maha Kuasa, yang menguasai alam semesta, yang berkuasa atas langit dan bumi, dan termasuk yang berkuasa terhadap dirinya sendiri (BR/B.6/173/Kthn).

Kutipan tersebut menunjukkan bahwa Bujang Remalun bisa mengimbangi hubungan dengan manusia dan juga hubungan dengan Sang Pencipta atau sering disebut dengan istilah habblumminnas dan habblumminallah.

Nilai yang terkait dengan ketuhanan lainnya yang dimiliki oleh Bujang Remalun adalah ketakwaannya terhadap Tuhan Yang Maha Kuasa. Ketakwaan tersebut terlihat pada kutipan berikut.

Selama itu pula ia berpuasa, tiada makan dan tiada minum (BR/B.10/174/Kthn).

Berdasarkan kutipan di atas terlihat bahwa Bujang Remalun memiliki sifat takwa. Ketakwaan tersebut tercermin ketika ia berpuasa tidak makan dan tidak minum. Hal ini mencerminkan bahwa Bujang Remalun bersikap taat dan menjalankan perintah Tuhan.

Dilihat dari keterkaitan cerita rakyat masyarakat Suku Pasemah Bengkulu Padang Guci, baik yang terkait dengan diri sendiri, terkait dengan orang/makhluk lain, maupun yang terkait dengan ketuhanan tidak hanya mengandung nilai yang positif, tetapi juga mengandung nilai yang negatif. 
Dari nilai positif dan negatif itu, nilai positiflah yang harus dicontoh atau diterapkan dalam kehidupan sehari-hari. Dengan kata lain, nilai pendidikan karakter yang baik untuk dijadikan sebagai contoh, sementara nilai negatif harus ditinggalkan. Namun, bukan berarti nilai negatif tidak penting untuk diketahui. Nilai negatif penting juga diketahui dengan tujuan untuk mengetahui bahwa nilai negatif itu tidak baik untuk dicontoh atau ditiru oleh anak, baik di sekolah maupun di masyarakat.

Terkait dengan pendidikan di sekolah yang ada di Padang Guci, penemuan nilainilai yang ada dalam cerita rakyat masyarakat Suku Pasemah Bengkulu Padang Guci dapat dijadikan sebagai referensi dalam pendidikan karakter. Hal tersebut menunjukkan bahwa cerita rakyat Suku Pasemah Bengkulu dapat dijadikan sebagai materi ajar dalam pembelajaran sastra di Sekolah Dasar khususnya yang ada di Padang Guci Kabupaten Kaur. Namun, untuk itu tentunya harus melalui proses pemilihan dan memperhatikan kriteria-kriteria cerita yang baik untuk dijadikan sebagai bahan ajar sastra.

\section{Relevansi Cerita sebagai Materi Pembe- lajaran Sastra}

Cerita rakyat masyarakat Suku Pasemah Bengkulu memuat nilai-nilai nasihat yang dapat dijadikan sebagai materi ajar, sehingga memiliki relevansi sebagai materi pembelajaran sastra. Hal ini disebabkan oleh adanya kesesuaian antara cerita yang ada dan kriteria materi pembelajaran sastra khususnya di kelas V Sekolah Dasar. Kenyataan tersebut memiliki kesamaan dengan penelitian yang dilakukan oleh Widiyono (2013). Dalam penelitian tersebut hasilnya menyatakan relevan apabila disampaikan dalam pendidikan formal dan nonformal dalam kaitannya dengan tujuan pendidikan moral atau karakter.

Adapun cerita yang relevan sebagai materi pembelajaran sastra, yaitu cerita yang berjudul: (1) Bujang Remalun; (2) Sang Kancil, Siput, dan Lengkukup; (3) Si Miskin; (4) Sang Beruk Besan dengan Kura-kura; (5) Pak Andir; (6) Sang Kancil dan Sang Harimau; (7) Sang Piatu Berdua dengan Nenek; (8) Elang Besan dengan Kura-kura; (9) Janji Kerbau. Kemudian, cerita yang tidak relevan, yaitu: (1) Pak Beluk; (2) Sang Piatu; dan (3) Sang Setue dan Sang Kancil.

Berdasarkan analisis karakter tokoh dan nilai pendidikan karakter yang terkandung di dalamnya, masing-masing cerita rakyat dalam penelitian ini banyak memiliki kandungan nilai karakter yang positif, tetapi ada juga nilai yang negatif. Cerita rakyat Suku Pasemah Bengkulu yang banyak mengandung nilai pendidikan karakter positif tersebut dapat dijadikan sebagi contoh dan yang negatif supaya ditinggalkan, sehingga cerita rakyat Suku Pasemah Bengkulu ini memungkinkan untuk dijadikan sebagai materi pembelajaran sastra. Pembelajaran Sastra dalam hal ini tentunya pembelajaran sastra yang ada di Sekolah Dasar, khususnya Sekolah Dasar yang berada di Padang Guci. Hal ini sejalan dengan penelitian yang pernah dilakukan oleh $\mathrm{Mu}$ naris (2011), yang mengemukakan bahwa pendidikan karakter dapat diintegrasikan pada pembelajaran sastra dalam mata pelajaran Bahasa Indonesia untuk tingkat sekolah dasar. Kemudian, kandungan nilai yang terdapat dalam cerita rakyat Suku Pasemah Bengkulu Padang Guci ini sekaligus merupakan wujud dari pembelajaran kontekstual dan berkarakter yang penting diajarkan kepada siswa.

Dilihat dari Kurikulum Tingkat Satuan Pedidikan (KTSP), materi sastra tentang cerita rakyat ini diajarkan di kelas $\mathrm{V}$ semes- 
ter satu. Adapun standar kompetensinya (SK) adalah "Memahami penjelasan narasumber dan cerita rakyat secara lisan" dan kompetensi dasarya (KD) adalah "Mengidentifikasi unsur cerita tentang cerita rakyat yang didengarnya".

Dari 12 cerita rakyat yang ditemukan dalam penelitian ini, ada 9 cerita yang relevan sebagai materi pembelajaran dan sebanyak 3 cerita yang tidak relevan. Ceritacerita yang tidak relevan itu karena hanya memenuhi satu kriteria yang sudah ditentukan yaitu hanya mengandung nilai estetis saja, sehingga cerita ini hanya memberikan hiburan saja, tanpa memberikan unsur pendidikan di dalamnya. Padahal, suatu karya sastra yang baik sebagai materi pembelajaran itu paling tidak mengandung dua kriteria, yaitu menghibur dan juga mendidik. Oleh karena itu, 3 cerita PB, SP, dan SSSK dinyatakan tidak relevan sebagai materi pembelajaran sastra, dalam hal ini pembelajaran sastra di sekolah dasar.

\section{PENUTUP}

Berdasarkan hasil penelitian dan pembahasan yang telah dilakukan, dapat diambil simpulan sebagai berikut.

Pertama, cerita rakyat masyarakat Suku Pasemah Bengkulu terdiri atas dua jenis, yaitu dongeng dan legenda. Berdasarkan jenis dan jumlah cerita yang ditemukan, terdapat 11 dongeng dan 1 legenda.

Kedua, nilai pendidikan karakter yang ditemukan dalam cerita, antara lain: (1) religius; (2) tanggung jawab; (3) peduli sosial, (4) disiplin; (5) rendah hati; (6) pemberani; (7) cerdik; (8) sabar; (9) patuh; (10), optimis; (11) kerja keras; (12) ikhlas menerima kekalahan; dan (13) menepati janji.

Ketiga, berdasarkan 12 cerita rakyat yang ditemukan, ada 9 cerita yang relevan sebagai materi pembelajaran sastra di SD, yaitu cerita: (1) Bujang Remalun; (2) Sang Kancil, Siput, dan Lengkukup; (3) Si Miskin; (4) Sang Beruk Besan dengan Kura-kura; (5) Pak Andir; (6) Sang Kancil dan Sang Harimau; (7) Sang Piatu Berdua sama Nenek; (8) Elang Besan dengan Kura-kura; dan (9) Janji Sang Kerbau. Kemudian, ada 3 cerita rakyat yang tidak relevan, yaitu cerita yang berjudul: (1) Pak Beluk; (2) Sang Piatu; dan (3) Sang Setue dan Sang Kancil.

Keempat, dilihat dari kurikulum 2006 atau Kurikulum Tingkat Satuan Pendidikan (KTSP), hasil penelitian ini dapat diimplikasikan dalam pembelajaran sastra, khususnya di Kelas V SD.

Hasil penelitian ini diharapkan dapat dimanfaatkan sebagai sarana untuk memperkaya khazanah pengetahuan tentang kesastraan, khususnya sastra lisan. Kemudian, bagi guru, hasil penelitian ini dapat dijadikan sebagai materi ajar dalam pembelajaran Bahasa dan Sastra Indonesia di lembaga-lembaga pendidikan terutama di SD.

\section{UCAPAN TERIMA KASIH}

Ucapan terima kasih disampaikan kepada Prof. Darmiyati Zuchdi, Ed.D. selaku pembimbing. Bapak Inul Asri dan Bapak Marlan selaku validator ahli. Nursida, Yunah, Satidah, Darwan, dan Abran selaku narasumber, serta semua pihak yang telah membantu dalam penelitian ini. Selain itu, ucapan terima kasih juga saya sampaikan kepada Redaktur Jurnal Pendidikan Karakter atas saran perbaikan yang diberikan. Semoga berbagai amal kebaikan dari berbagai pihak tersebut mendapat pahala dari Allah SWT.

\section{DAFTAR PUSTAKA}

Agung, Leo. 2011. "Character Education Integration in Social Studies Learning". 
International Journal of History Education, Th. XII, No.2, Dec., hlm. 392-403.

Barone, Diane M. 2011. Children's Literature in the Classroom Engaging Lifelong Reader,s. New York: The Guilford Press.

Danandjaja, James. 1994. Folklor Indonesia. Jakarta: Pustaka Utama Grafiti.

Lickona, Thomas. 2013. Education for Character: Mendidik untuk Membentuk Karakter (Terjemahan Juma Abdu Wamaungo). New York: Catherine Gafell.

Munaris. 2011. "Pemanfaatan Buku KecilKecil Punya Karya sebagai Bahan Pembelajaran Sastra untuk Pengembangan Karakter". Jurnal Pendidikan Karakter, Th.I, No.1, Oktober, hlm. 87-109.

Muslich, Masnur. 2013. Pendidikan Karakter: Menjawab Tantangan Krisis Multidimensional. Jakarta: PT Bumi Aksara.

Nurgiyantoro, Burhan. 2011. “Wayang dan Pengembangan Karakter Bangsa". Jurnal Pendidikan Karakter, Th.I, No.1, Oktober, hlm.18-34.

Nurgiyantoro, Burhan. 2013a. Teori Pengkajian Fiksi. Yogyakarta: Gadja Mada University Press.

Nurgiyantoro, Burhan. 2013b. Sastra Anak: Pengantar Pemahaman Dunia Anak. Yogyakarta:Gadja Mada University Press.
Peraturan Pemerintah RI. Nomor 57 Tahun 2014, tentang Pengembangan, Pembinaan, dan Pelindungan Bahasa dan Sastra, Serta Peningkatan Fungsi Bahasa Indonesia.

Rosyiidah, Afiifah A. 2013. "Pendidikan Karakter pada Classic Fairy Tales". Jurnal Pendidikan Karakter, Th.III, No.3, Oktober, hlm.250-265.

Sugirin. 2011. "Character Education for the Efl Student-teachers". Cakrawala Pendidikan, Th.XXX Edisi Khusus Dies Natalis UNY, hlm.15-27.

Wibowo, Agus. 2013. Pendidikan Karakter Berbasis Satra: Internalisasi Nilai-Nilai Karakter melalui Pengajaran Sastra. Yogyakarta: Pustaka Belajar.

Widiyono, Yuli. 2013. "Nilai Pendidikan Karakter Tembang Campursari Karya Manthous". Jurnal Pendidikan Karakter. Th.III, No.2, Juni, hlm. 231-239.

Wiyani, Novan A. 2013. Membumikan Pendidikan Karakter di SD: Konsep, dan Strategi. Yogyakarta: Ar-Ruzz Media.

Zuchdi, Darmiyati, dkk. 2013. Model Pendidikan Karakter: Terintegrasi dalam Pembelajaran dan Pengembangan Kultur Sekolah. Yogyakarta: CV. Multi Presindo MP. 